\title{
The Occurrence of Corundum-Rich Metabauxite in the Qaradash District, NW Iran
}

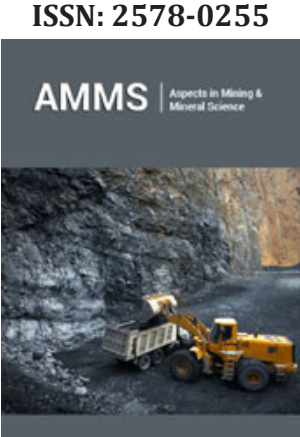

*Corresponding author: Ali Abedini, Department of Geology, Faculty of Sciences, Urmia University, 5756151818 Urmia, Iran

Submission: 侮 January 25, 2021

Published: 想 February 01, 2021

Volume 6 - Issue 2

How to cite this article: Ali Abedini, Maryam Khosravi. The Occurrence of Corundum-Rich Metabauxite in the Qaradash District,NW Iran. Aspects Min Miner Sci. 6(2). AMMS. 000632. 2021. DOI: 10.31031/AMMS.2021.06.000632

Copyright@Ali Abedini, This article is distributed under the terms of the Creative Commons Attribution 4.0 International License, which permits unrestricted use and redistribution provided that the original author and source are credited.

\author{
Ali Abedini ${ }^{1 *}$ and Maryam Khosravi² \\ ${ }^{1}$ Department of Geology, Faculty of Sciences, Urmia University, Iran \\ ${ }^{2}$ Department of Earth Sciences, College of Sciences, Shiraz University, Iran
}

\section{Opinion}

The corundum-rich metabauxites were, very rare worldwide, reported in the AtticCycladic metamorphic complex in Greece and the southern and western margins of the Menderes Massif in southwestern Turkey. The Qaradash bauxite deposit is located in the IranHimalayan karst bauxite belt, $25 \mathrm{~km}$ northwest of Shahindezh city, northwestern Iran (Figure 1a). The rock units in the Qaradash district mainly occur in an asymmetric fold and in the core of an anticline (Figure 1b). They, from the oldest to youngest, include the Permian carbonates of the Ruteh Formation, the Triassic sandstone and carbonate of the Elika Formation, and the Plio-Quaternary sandy conglomerate. Carbonates of the Ruteh Formation are dark grey in color that were intruded by the Oligocene monzonite and quartz monzonite intrusions. The marbles occur at the contact of these intrusions with carbonates of the Ruteh Formation. The bauxite horizons occur as 7-15-m-thick layers along the contact of carbonates of the Ruteh Formation (Permian) and sandstone and carbonate of the Elika Formation (Triassic) that were also affected by these intrusive masses and were partially converted to metabauxite.

\section{Methods}

The mineralogical analysis of the whole powered samples was carried out by powder X-ray diffraction (PXRD) using a Siemens D5000 X-ray diffractometer at the Geological Survey of Iran, Tehran under the following conditions: $\mathrm{Cu}-\mathrm{K} \alpha$ radiation, $40 \mathrm{kV}, 30 \mathrm{~mA}$, scanning speed $8^{\circ}$ per minute, and scan range $2^{\circ}-60^{\circ}$. Whole-rock chemical analyses of the bauxites were analyzed at the Activation Laboratories Ltd. (ALS Chemex, Canada). The analysis was performed on approximately $0.25 \mathrm{~g}$ of the powdered samples, digested with lithium tetraborate and lithium metaborate fluxes, and heated in an oven at $1000{ }^{\circ} \mathrm{C}$. The resultant melt was cooled and then diluted in nitric acid $(100 \mathrm{ml})$. Finally, these solutions were chemically analyzed for major elements by inductively coupled plasma-atomic emission spectrometry (ICP-AES) and for trace elements (including rare earth elements) by inductively coupled plasma-mass spectrometry (ICP-MS). The detection limit for major elements, such as oxides and total loss on ignition (LOI) is $0.01 \mathrm{wt} \%$, and for trace elements varies between 0.01 and $10 \mathrm{ppm}$. LOI was gravimetrically estimated after overnight heating at $950{ }^{\circ} \mathrm{C}$.

\section{Results}

The bauxite ores in the Qaradash district can be divided into two categories, based upon mineral paragenetic features, as follows: they are far away from the intrusive masses, and are made up mainly of diaspore, boehmite, kaolinite, anatase, rutile, illite, goethite, and hematite (Figure 1c). In contrast, they are in nearby the intrusive masses, and consist of corundum, diaspore, hematite, rutile, pyrophyllite, kaolinite, and quartz (Figure 1d). Diaspore, anatase, and goethite are the most abundant minerals in the former, whereas corundum is the most abundant Al-bearing phase in the latter. The occurrence of pyrophyllite and the absence of anatase and goethite are the most important mineralogical features of the Qaradash metabauxite. Geochemical studies indicate that there is a significant difference in $\mathrm{Al}_{2} \mathrm{O}_{3}, \mathrm{TiO}_{2}$, $\mathrm{LOI}$, and $\mathrm{V}$ contents of these two categories of the ores. The $\mathrm{Al}_{2} \mathrm{O}_{3}$ (47.99-49.52 wt\%) and $\mathrm{TiO}_{2}$ (5.23-5.88 wt\%) contents in the metabauxites have an average enrichment of 1.17 and 1.13 , respectively, compared with bauxite ores far away from the intrusive masses. In contrast, the LOI (9.23-9.44 wt\%) and V (193-196ppm) contents in the metabauxites have an average enrichment of 0.68 and 0.31 , respectively, compared with bauxite ores far away from the intrusive masses. 


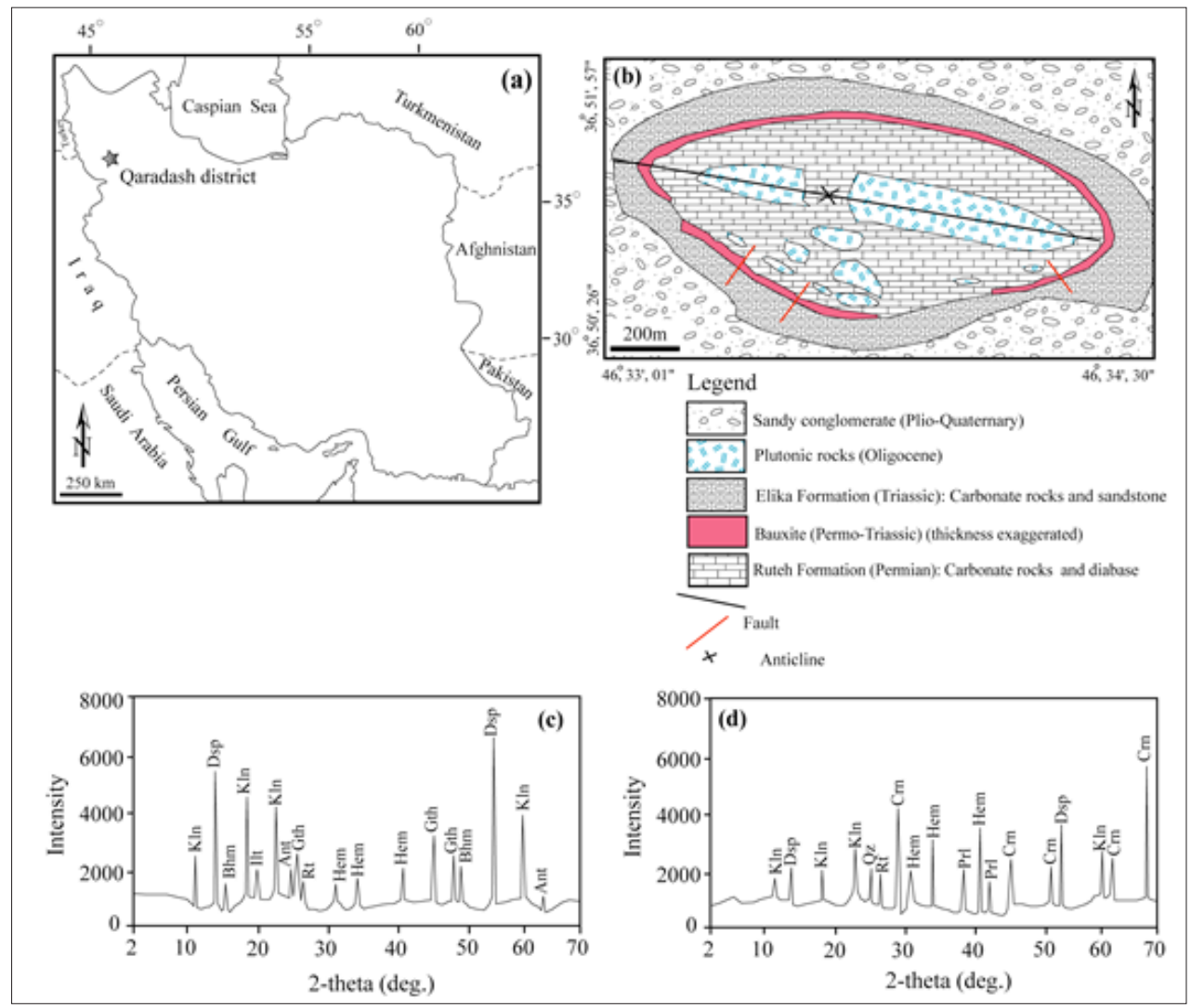

Figure 1: The position of the studied metabauxite (a), simplified geological map (b), and powder-XRD patterns of the representative bauxite ores (c \& d). Ant=Anatase, Bhm=Boehmite, Crn=Corundum, Dsp=Diaspore, Gth=Goethite, Hem=Hematite, Ilt=Illite, Kln=Kaolinite, Prl=Pyrophyllite, Qz=Quartz, Rt=Rutile.

\section{Conclusion}

A rare geological phenomena in northwestern Iran is the occurrence of metabauxites in the Qaradash district. Metabauxites are a product of the emplacement of the Oligocene monzonite and quartz monzonite intrusions into the Permian carbonate bedrocks through the processes of contact metamorphism. They occur along the contact of the Permian carbonates of the Ruteh Formation and the Triassic sandstone and carbonate of the Elika Formation. Compared with bauxite ores far away from the intrusive masses, metabauxites are characterized by the occurrence of corundum and pyrophyllite, the absence of anatase and goethite, high $\mathrm{Al}_{2} \mathrm{O}_{3}$ and $\mathrm{TiO}_{2}$ contents, and low LOI contents. 